\title{
Workshop Pemanfaatan Teknologi untuk Memantau Tumbuh Kembang dan Kesehatan Balita
}

\author{
Dwi Puspitasari ${ }^{1}$, Mamluatul Hani'ah ${ }^{2}$, Candra Bella Vista ${ }^{3}$, \\ Ika Kusumaning Putri ${ }^{4}$, Wilda Imama Sabila ${ }^{5}$ \\ 1,2,3,4,5 Jurusan Teknologi Informasi Politeknik Negeri Malang, Alamat: J1. Soekarno Hatta No. 9 Malang, \\ e-mail: ${ }^{1}$ dwi.puspitasari@polinema.ac.id, ${ }^{2}$ mamluatulhaniah@polinema.ac.id, ${ }^{3}$ bellavista@polinema.ac.id, \\ 4ikakputri@polinema.ac.id, ${ }^{5}$ wildaimama@polinema.ac.id
}

\begin{abstract}
Abstrak
Anak merupakan sumber daya manusia yang penting untuk kelangsungan dan kemajuan suatu bangsa. Oleh sebab itu pemantauan tumbuh kembang dan kesehatan anak menjadi sangat penting dilakukan secara berkala dengan harapan Indonesia dapat menghasilkan generasi unggul dan berkualitas. Seiring perkembangan teknologi informasi para orang tua tentunya membutuhkan solusi yang mudah, praktis, dan efisien untuk memantau perkembangan dan kesehatan balita. Penggunaan aplikasi mobile dapat digunakan sebagai solusi untuk orang tua milenial. Oleh karena itu, kegiatan pengabdian masyarakat ini bertujuan untuk mengenalkan dan melatih orang tua di Posyandu Rajawali untuk menggunakan Aplikasi PrimaKu. Aplikasi PrimaKu adalah aplikasi digital yang diprakarsai oleh Ikatan Dokter Anak Indonesia (IDAI) sebagai upaya mempermudah orang tua di Indonesia dalam memantau tumbuh kembang anak sejak dini secara berkala dan berkelanjutan. Metode yang digunakan dalam kegiatan pengabdian ini adalah wawancara, persiapan pelaksanaan workshop, pelatihan penggunaan aplikasi PrimaKu, serta evaluasi dengan memberikan kuesioner kepada peserta workshop. Berdasarkan hasil kuesioner, peserta memberikan respon baik terhadap pelaksanaan kegiatan berdasarkan kebermanfaatan program, relevansi serta kejelasan materi. Kebermanfaatan program ditunjukkan melalui hasil kuesioner yang menyatakan bahwa $78.6 \%$ peserta setuju kegiatan workshop ini sangat bermanfaat. Sedangkan kejelasan materi dinyatakan dengan hasil $85.7 \%$ peserta setuju bahwa materi yang disampaikan sangat mudah dimengerti dan dipraktikkan.
\end{abstract}

Kata kunci-PrimaKu, posyandu, tumbuh kembang, kesehatan balita

\section{PENDAHULUAN}

Perkembangan anak di usia dini memegang peranan yang sangat penting dalam perkembangan seorang individu. Periode penting dalam tumbuh kembang anak pada tiga tahun pertama berlangsung secara pesat dan menentukan masa depan anak kelak [1]. Sehingga, pada masa emas tersebut pemantauan perkembangan balita secara teratur menjadi hal yang sangat penting untuk mendeteksi apakah terdapat penyimpangan dalam tumbuh kembang balita. Terdapat 3 (tiga) aspek yang perlu diperhatikan dalam tumbuh kembang balita. Pertama adalah aspek pertumbuhan yang penting digunakan untuk menentukan status gizi balita. Dapat diamati dari berat badan, tinggi badan, dan lingkar kepala. Yang kedua adalah aspek perkembangan untuk mengetahui adanya keterlambatan perkembangan anak, gangguan daya lihat, dan gangguan daya dengar. Ketiga adalah aspek mental dan emosional yang digunakan untuk mengetahui adanya masalah mental emosional, autism, dan gangguan pemusatan perhatian dan hiperaktivitas [2].

Terdapat berbagai metode stimulasi dan deteksi dini tumbuh kembang balita yang telah dikembangkan oleh para ahli diantaranya melalui kegiatan Stimulasi, Deteksi, dan Intervensi Dini Tumbuh Kembang (SDIDTK) [3]. Aspek SDIDTK sudah ada di dalam Buku KIA. Buku Kesehatan Ibu dan Anak (Buku KIA) berisi catatan kesehatan ibu (hamil, bersalin dan nifas) dan anak (bayi baru lahir sampai anak usia 6 tahun) serta berbagai informasi cara memelihara dan merawat kesehatan ibu dan anak [4]. Buku KIA diberikan kepada setiap ibu hamil. Buku KIA ini dapat diperoleh di Posyandu, Polindes/ Poskesdes, Puskesmas Pembantu, Puskesmas, bidan praktik, dokter praktik, rumah bersalin dan rumah sakit.

Penggunaan buku KIA dianggap menjadi tidak praktis dikarenakan keterbatasan informasi, 
seperti tidak adanya pengingat untuk waktu imunisasi dan terbatasnya informasi mengenai kesehatan. Seiring perkembangan teknologi informasi para orang tua tentunya membutuhkan solusi yang mudah, praktis, dan efisien untuk memantau perkembangan dan kesehatan balita. Apalagi sebagian besar generasi milenial tersebut sudah menjadi orang tua. Menurut Badan Pusat Statistik (BPS), penduduk Indonesia yang lahir antara tahun 1980-2000 sebagian besar telah menjadi orang tua yang terpapar pesatnya perkembangan teknologi [5]. Penggunaan aplikasi mobile dapat digunakan sebagai solusi untuk orang tua milenial.

Salah satu aplikasi mobile yang dapat digunakan untuk memantau tumbuh kembang dari anak adalah aplikasi PrimaKu. Aplikasi PrimaKu adalah aplikasi digital yang diprakarsai oleh Ikatan Dokter Anak Indonesia (IDAI) [6]. Aplikasi ini dapat digunakan oleh para orang tua agar dapat memantau pertumbuhan dan perkembangan anaknya melalui smartphone yang dimiliknya. Jika terdapat ketidaksesuaian terhadap pertumbuhan dan perkembangan terhadap anak maka dapat dideteksi lebih dini [7]. Aplikasi PrimaKu menjadi semacam panduan bagi orang tua untuk memastikan tumbuh kembang anaknya berjalan optimal dan terhindar dari berbagai penyakit [8]. Fitur-fitur aplikasi PrimaKu yaitu sebagai berikut [9].

1. Menu Artikel yang berisi kumpulan artikel yang diterbitkan oleh dokter IDAI dan dapat diakses secara gratis oleh pengguna aplikasi Primaku.

2. Menu Imunisasi yang berisi informasi jadwal lengkap vaksinasi, detail vaksinasi, pengingat jadwal, dan data vaksin.

3. Menu Grafik/Chart yang menampilkan grafik pertumbuhan berat badan, panjang bada, indeks masa tubuh, dan lingkar kepala berdasarkan usia.

4. KPSP Tumbuh Kembang yang memberikan informasi mengenai tahapan perkembangan anak dan stimulasi perkembangan anak.

Posyandu Rajawali adalah kelompok Posyandu yang berada di Desa Tamanharjo, Singosari, Kabupaten Malang. Tepatnya di Komplek TNI-AU Kartanegara Blok A Desa Tamanharjo Kecamatan Singosari, Kabupaten Malang. Kelompok Posyandu Rajawali beranggotakan 112 Balita, 56 laki-laki dan 56 perempuan. Kegiatan Posyandu Rajawali diadakan setiap bulan pada hari kamis, minggu ke 2 (dua). Ibu-ibu yang tergabung di dalam kelompok Posyandu Rajawali mayoritas adalah ibu rumah tangga dengan rentang usia antara 25 hingga 35 tahun. Oleh karena itu, kegiatan pengabdian masyarakat ini bertujuan untuk mengenalkan dan melatih orang tua di Posyandu Rajawali untuk menggunakan Aplikasi PrimaKu. Diharapkan Aplikasi PrimaKu mempermudah orang tua di Posyandu Rajawali dalam memantau tumbuh kembang anak sejak dini secara berkala dan berkelanjutan.

\section{METODE}

Metode yang digunakan pada kegiatan pengabdian kepada masyarakat ini adalah sebagai berikut :

1. Wawancara kepada ketua posyandu untuk menggali permasalahan yang ada di posyandu. Dari hasil wawancara didapatkan permasalahan utama yang menjadi prioritas untuk diselesaikan yaitu para orangtua di Posyandu Rajawali dalam memantau perkembangan dan kesehatan anak dengan menggunakan buku KIA (Kesehatan Ibu dan Anak) tidak terdapat pengingat untuk jadwal Imunisasi dari IDAI.

2. Persiapan pelaksanaan workshop, pada tahap persiapan dilakukan pembuatan materi pelatihan dengan mencari referensi-referensi dari situs resmi maupun media sosial dari IDAI, pembuatan rundown acara sehingga acara dapat dilaksanakan secara tertib, persiapan zoom meeting dan koneksi internet dimana kegiatan pelatihan ini dilakukan secara daring karena adanya Covid-19 serta tidak diperbolehkan adanya kerumunan. Persiapan selanjutnya adalah pembagian tugas tim saat melakukan workshop dimana dalam pembagian ini terdapat seorang MC yang akan memandu acara, moderator, dua orang pemateri, dan satu orang host yang memandu peserta ketika peserta mengalami kesulitan saat acara berlangsung.

3. Pelatihan penggunaan aplikasi mobile PrimaKu dan pembekalan pengetahuan mengenai standar perkembangan dan kesehatan balita. Kegiatan ini dilaksanakan secara daring mengingat masih mewabahnya virus Covid-19 di Indonesia. Sejak awal munculnya wabah, Organisasi Kesehatan Dunia (WHO) sudah menggaungkan social distancing, yang lalu diubah menjadi physical distancing untuk mengurangi penyebaran Covid19 [10]. 
Pelatihan ini terdiri dari 3 tahapan yaitu sebagai berikut [11]:

1. Ceramah dan diskusi sebagai pembekalan pengetahuan mengenai standar perkembangan dan kesehatan balita.

Materi diberikan oleh salah satu dosen yang memaparkan mengenai perkembangan balita, kesehatan balita, pemantauan perkembangan dan kesehatan balita, serta pemanfaatan teknologi untuk membantu pemantauan perkembangan dan kesehatan balita.

2. Praktik penggunaan aplikasi mobile PrimaKu.

Praktik penggunaan aplikasi diawali dengan pengenalan aplikasi PrimaKu, cara registrasi dan bagaimana menggunakan aplikasi PrimaKu untuk memantau pertumbuhan, perkembangan, dan kesehatan balita.

3. Evaluasi kegiatan

Untuk mengetahui keberhasilan kegiatan pengabdian kepada masyarakat ini, dilakukan pengujian sejauh mana pelatihan penggunaan aplikasi PrimaKu dapat diterima dan memberikan manfaat bagi orang tua di Posyandu Rajawali. Kuesioner digunakan untuk mengetahui respon peserta yaitu para orang tua di Posyandu Rajawali.

\section{HASIL DAN PEMBAHASAN}

\subsection{Hasil}

Pelaksanaan kegiatan Pengabdian Pada Masyarakat berupa workshop pemanfaatan teknologi untuk memantau tumbuh kembang dan kesehatan balita menggunakan aplikasi PrimaKu di Posyandu Rajawali Desa Tamanharjo Singosari adalah sebagai salah satu bentuk menyebarluaskan kemajuan teknologi yang positif dan sekaligus dapat mendukung program IDAI (Ikatan Dokter Anak Indonesia) untuk Membangun Anak Indonesia (PRIMA). Setelah pelaksanaan program pengabdian kepada masyarakat ini diharapkan dapat memberikan pemahaman dan pengetahuan dalam menggunakan aplikasi PrimaKu kepada para orang tua yang memiliki anak usia balita di Posyandu Rajawali, Desa Tamanharjo, Kecamatan Singosari, Kabupaten Malang.

Tujuan yang dicapai dalam kegiatan pengabdian kepada masyarakat ini adalah sebagai berikut:

1. Orang tua di Posyandu Rajawali, Desa Tamanharjo, Singosari mendapatkan pengetahuan mengenai standar perkembangan dan kesehatan balita.
2. Orang tua di Posyandu Rajawali, Desa Tamanharjo, Singosari memahami pentingnya memantau perkembangan dan kesehatan balita secara teratur dan terencana dengan memanfaatkan aplikasi mobile PrimaKu.

3. Melaksanakan salah satu unsur Tri Dharma Perguruan Tinggi yang berkaitan dengan pengenalan teknologi kepada masyarakat.

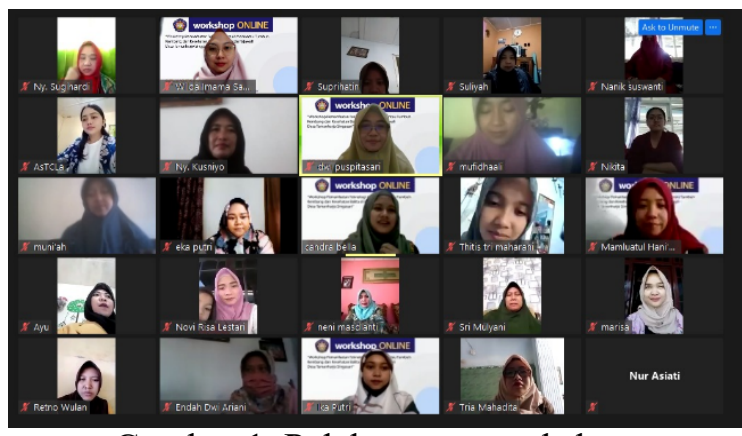

Gambar 1 Pelaksanaan workshop

Tingkat keberhasilan atau evaluasi dari program kegiatan pengabdian diukur melalui kuesioner yang diberikan kepada peserta di akhir pelaksanaan workshop. Peserta dalam kegiatan ini berjumlah 20 orang dimana 14 di antaranya bersedia mengisi kuesioner evaluasi kegiatan. Kuesioner ini terdiri dari 6 soal yang menanyakan mengenai kebermanfaatan workshop, relevansi materi, serta kejelasan penyampaian materi. Setiap soal memiliki 5 pilihan jawaban dimana nilai 1 berarti sangat kurang dan nilai 5 menunjukkan sangat baik.

Berdasarkan pengamatan selama pelaksanaan kegiatan terlihat antusiasme yang sangat baik dari para peserta. Dibuktikan dari 20 peserta yang diundang, hadir $100 \%$ saat kegiatan pelatihan dilaksanakan. Pada saat pelaksanaan kegiatan, peserta workshop mempunyai keinginan yang cukup besar untuk menambah pengetahuan tentang penggunaan aplikasi PrimaKu yang ditunjukkan pada tanggapan kuesioner menyatakan $78.6 \%$ peserta menyatakan kegiatan workshop ini sangat bermanfaat dan sisanya menganggap kegiatan workshop ini bermanfaat. Dengan rata-rata peserta pelatihan adalah ibu-ibu dengan usia 30-55 tahun, tingkat pendidikan SMA, SMK, MAN, Sarjana dan sederajat dapat dikatakan secara akademis termasuk pendidikan menengah dan pendidikan tinggi, sehingga metode pelatihan yang digunakan mudah dimengerti dan mudah dilaksanakan. Sebanyak $85.7 \%$ dari 20 orang peserta menyatakan materi yang disampaikan sangat mudah dimengerti dan dipraktikkan, sedangkan $14.3 \%$ sisanya menyatakan materi yang disampaikan 
mudah dimengerti dan dipraktikkan. Antusiasme positif juga ditunjukkan dari hasil kuisioner sebanyak $100 \%$ peserta bersedia untuk mengikuti kegiatan workshop serupa atau merupakan kegiatan lanjutan dari pelatihan pemanfaatan aplikasi PrimaKu.

Tabel 1 kegiatan pengabdian desa dan kota

\begin{tabular}{lllllll}
\hline No & \multicolumn{2}{c}{ Pertanyaan } & \multicolumn{5}{c}{ Tanggapan (\%) } \\
\cline { 3 - 7 } & & 1 & 2 & 3 & 4 & 5 \\
\hline 1 & Apakah kegiatan & 0 & 0 & 0 & 21,4 & 78,6 \\
& $\begin{array}{l}\text { workshop yang } \\
\text { dilaksanakan } \\
\text { bermanfaat? }\end{array}$ & & & & & \\
& & & & & & \\
& & & & &
\end{tabular}

2

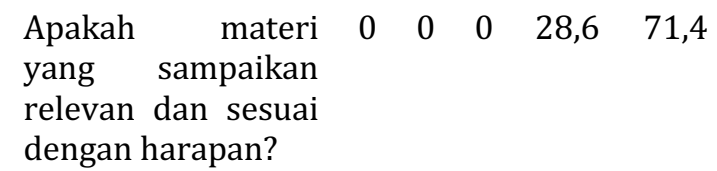

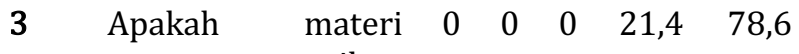 yang sampaikan sudah mencukupi untuk mampu menggunakan aplikasi PrimaKu?

4 Apakah pemateri $0 \begin{array}{lllll}0 & 0 & 0 & 14,3 & 85,7\end{array}$ mampu mempresentasikan materi dengan baik (mudah dimengerti dan dipraktikkan)?

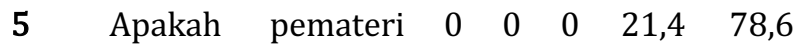
memahami materi yang disajikan dan dapat menjawab pertanyaan dengan baik?

6 Jika $\quad \begin{array}{llllll}6 \text { kegiatan } & 0 & 0 & 0 & 50,0 & 50,0\end{array}$ serupa dilaksanakan

kembali, apakah Anda bersedia untuk berpartisipasi kembali?

RATA-RATA \begin{tabular}{ccccc}
0 & 0 & 0 & 26,2 & 73,8 \\
\hline
\end{tabular}

\subsection{Pembahasan}

Keberhasilan yang ditunjukkan melalui hasil pengamatan selama kegiatan pelatihan berlangsung dan analisis hasil kuesioner peserta, tidak serta merta menjamin keberhasilan kegiatan ini yang sesungguhnya. Kegiatan ini dikatakan sukses apabila para orang tua balita di Posyandu Rajawali, Desa Tamanharjo, Singosari dapat memanfaatkan aplikasi PrimaKu sebagai sarana untuk memantau perkembangan dan kesehatan balita.

Setelah pelaksanaan Pengabdian Pada Masyarakat ini dapat dievaluasi faktor penghambat dan faktor pendorong keberhasilan dari pelaksanaan kegiatan workshop ini, sebagai berikut:

a. Faktor penghambat

Hambatan utama pelaksanaan workshop pemanfaatan teknologi untuk memantau tumbuh kembang dan kesehatan balita menggunakan aplikasi PrimaKu di Posyandu Rajawali Desa Tamanharjo Singosari adalah terjadinya pandemi covid-19. Semula kegiatan direncanakan dilaksanakan secara offline sehingga pelatihan dapat maksimal terutama pada saat sesi praktikum, harus diubah secara daring. Hal ini menyebabkan pada saat pelaksanaan pelatihan, beberapa dari peserta tidak bisa mencoba praktik menggunakan aplikasi PrimaKu secara langsung dikarenakan keterbatasan gawai yang dimiliki. Namun hal tersebut dapat teratasi dengan penyampaian materi yang sangat baik dan penuh kesabaran serta ketelatenan dari pemateri. Selain itu penyediaan modul tercetak memberikan kemudahan bagi peserta untuk dapat membaca dan mempraktekkan sendiri penggunaan aplikasi PrimaKu setelah pelatihan berakhir.

\section{b. Faktor pendorong}

Dengan terselenggaranya Pengabdian kepada Masyarakat ini dirasakan ada beberapa faktor pendorong yang menjadikan kegiatan ini dapat dilaksanakan dengan lancar, yaitu:

- Minat dan antusiasme para peserta dalam mengikuti pelatihan sangat besar sekali, sehingga mempermudah dalam proses penyampaian materi.

- Keaktifan peserta untuk bertanya mengenai pemanfaatan fitur-fitur aplikasi PrimaKu menjadikan sesi diskusi lebih hidup dan menambah pemahaman bagi peserta lainnya.

- Dukungan dari ketua RW dan ketua Posyandu Desa Tamanharjo Singosari yang turut hadir dan ikut serta membantu mempublikasikan kegiatan ini kepada para orang tua balita di Posyandu Rajawali Desa Tamanharjo Singosari.

- Salah satu anggota panitia yang berdomisili di Desa Tamanharjo Singosari bertidak cekatan sebagai helpdesk untuk membantu selama pelaksanaan di lapangan, seperti membantu 
jika terdapat masalah koneksi dari peserta dan turut memandu dalam praktik penggunaan aplikasi PrimaKu.

\section{KESIMPULAN}

Hasil dari evaluasi atau kuesioner yang diberikan kepada peserta diperoleh kesimpulan bahwa kegiatan workshop yang dilaksanakan telah sesuai dengan tujuan yang ingin dicapai. Orang tua di Posyandu Rajawali, Desa Tamanharjo, Singosari mendapatkan manfaat melalui kegiatan pengabdian kepada masyarakan ditunjukkan dengan 78.6\% peserta menyatakan kegiatan workshop sangat bermanfaat dan sisanya menganggap kegiatan workshop bermanfaat.

Orang tua di Posyandu Rajawali, Desa Tamanharjo, Singosari memahami pentingnya memantau perkembangan dan kesehatan balita secara teratur dan terencana dengan memanfaatkan aplikasi mobile PrimaKu serta memahami materi yang disampaikan. Hasil evaluasi menunjukkan dari total 20 orang peserta, sebanyak $85.7 \%$ peserta menyatakan materi yang disampaikan sangat mudah dimengerti dan dipraktikkan. Peserta workshop di Posyandu Rajawali juga merasa cukup puas dengan kegiatan yang diadakan terlihat dari hasil kuesioner dimana nilai 4 (baik) dan 5 (sangat baik) sebesar $26,2 \%$ dan $73.8 \%$.

\section{SARAN}

Untuk memaksimalkan hasil pelatihan, maka pada kegiatan selanjutnya dapat dilaksanakan secara luring apabila pandemi telah berakhir sehingga akan lebih memudahkan peserta ketika praktik penggunaan aplikasi dan jumlah peserta bisa diperbanyak sehingga kemanfaatan kegiatan bisa lebih luas lagi.

\section{UCAPAN TERIMA KASIH}

Penulis mengucapkan terima kasih kepada Politeknik Negeri Malang yang telah memberi dukungan moral dan finansial terhadap kegiatan pengabdian ini.

\section{DAFTAR PUSTAKA}

[1] Narendra M.S., 2002, Buku Ajar Tumbuh
Kembang Anak dan Remaja Edisi ke-1 IDAI. Jakarta: Sagung Seto.

[2] Fazrin, I., Widiana, D., Trianti, I.R., Baba, K.J., Nuralita, A. dan Smaut, M.Y., 2018, Pendidikan Kesehatan Deteksi Dini Tumbuh Kembang pada Anak di PAUD Lab School UNPGRI Kediri, Journal of Community Engagement in Health, 1(2), 6-14. DOI: 10.30994/jceh.vli2.8.

[3] Kementerian Kesehatan RI, 2013, Pedoman Pelaksanaan Stimulasi, Deteksi dan Intervensi Dini Tumbuh Kembang Anak di Tingkat Pelayanan Kesehatan Dasar, Jakarta.

[4] Kementerian Kesehatan RI, 2016, Kementerian Kesehatan RI Buku Kesehatan Ibu dan Anak, Kementerian Kesehatan dan JICA (Japan International Cooperation Agency), Jakarta.

[5] Anonim, 2019, Orang Tua Milenial, Terapkan Digital Parenting!, https://ayobandung.com/ read/2019/07/10/57317/orang-tua-milenialterapkan-digital-parenting, diakses tanggal 18 September 2020.

[6] Anonim, 2020, Aplikasi Primaku dan PrimaPro, www.idai.or.id/newsevent/news/ aplikasi-primaku-dan-primapro, diakses tanggal 2 Januari 2020.

[7] Arisanti, Septia, 2019, PrimaKu, Aplikasi Digital untuk Memantau Tumbuh Kembang Anak, https://kumparan.com/babyologist/prima ku-aplikasi-digital-untuk-memantau-tumbuhkembang-anak-1548439358474551522/full, diakses tanggal 18 September 2020.

[8] Parentstory, 2020, IDAI Luncurkan Aplikasi Konsultasi Daring Gratis, https://www. parentstory.com/blog/idailuncurkan-aplikasi konsultasi-daring-gratis, diakses tanggal 18 September 2020.

[9] Tim PrimaPro, 2018, PRIMAKU Fitur Aplikasi Android Ver. 1.02, IDAI, Jakarta.

[10] Dwiputra, K. O., 2020, Kapolri Cabut Maklumat Larangan Berkumpul Saat Pandemi COVID-19, Amankah?, https://www.klikdokter.com/infosehat/read/3641017/kapolri-cabut-maklumatlarangan-berkumpul-saat-pandemi-covid-19amankah, diakses tanggal 18 September 2020.

[11] Lensoni, Yulinar, Rahmawati, C., Meliyana, Safitri, E. dan Rahmayani, C., 2020, Pelatihan Pencegahan Penularan Penyakit Scabies dan Peningkatan Hidup Bersih dan Sehat Bagi Santriwan, DINAMISIA: Jurnal Pengabdian Kepada Masyarakat, 4(3), 470-475. https://doi.org/10.31849/dinamisia.v4i3.4519. 